\title{
The Cleavage of Clientelism at Local Democracy (A Case of East Nusa Tenggara)
}

\author{
Rudi Rohi ${ }^{1}$, Nanang Indra Kurniawan ${ }^{2}$ \\ \{rudirohi@gmail.com ${ }^{1}$, nanang.kurniawan@gmail.com² \\ Doctoral Student at Department of Politics and Government, FISIPOL, UGM, \\ \& Lecturer at Department of Politics, FISIP, UNDANA ${ }^{1}$ \\ Lecturer at Department of Politics and Government, FISIPOL, UGM ${ }^{2}$
}

\begin{abstract}
This paper aims to explain clientelism politics at the local democracy by going beyond the dichotomic way. The dominant debates on clientelism have been trapped in a feudal-modern dichotomy outlook. Clientelism, thus, is only defined as an exchange relation in terms of identity and money politics. This study explores different findings, where the shape of clientelism depends on the dimension of the relationship that forms cleavage of clientelism into some authentic variants including identity primordialism, identity instrumentalism, materialist primordialism, and materialist instrumentalism. Based on these findings, I argue that clientelism in local democracy is divided into several authentic variants which are identity and materialist or money politics, and other variants established from the linkages of identity and money politics. Furthermore, this study contributes to providing a relational explanation between clientelism, identity, and money politics in which clientelism is infinite to either the dichotomies social identity-materialistic or feudal-modern.
\end{abstract}

Keywords: Cleavage Clientelism; Class Politics; Local Democracy

\section{Introduction}

This article explores the practice of clientelism within the local democracy in East Nusa Tenggara (NTT). It examines the existing clientelist relation in the context of transitioning society dominated by the political class - who derive their revenues and income primarily from the state through formal and informal ways (Vel, 2008). The main question addressed in this article is how are clientelism practice and cleavage manifested in the local democracy. Furthermore, it is meant to highlight how the variants are formed as well as the operation takes place. Clientelism debates have been dominated by the dichotomic simplified as a feudalmodern spectrum (Lauth, 2004; van de Walle, 2007; Ansel and Mitchell, 2011). The debate is polarized into old clientelism which refers to exchange relations based on feudality, and new clientelism pinpointing on modernity (Mason, 1986; Piattoni, 2001; Hopkin, 2006; Allum dan Allum, 2008). Clientelism is thus defined as an exchange relation in terms of patronage and clientelism politics (Kitschelt dan Wilkinson, 2007; Aspinal, 2010; Aspinall dan Sukmajati, 2016; Berenschot, 2018; Fossati et. al, 2020) with identity politics on one hand and materialist or money politics on the other hand. 
Unfortunately, the outlook is historically constructed, particularly with West Europe and the Mediterranean traditions. Whilst, the practice of clientelism within transition societies in emerging democracy countries, where modernization occurred but feudality persist with political class domination and diverse clientelism, such as in the periphery - local democracy - of Indonesia (van Klinken, 2007; Vel, 2008; van Klinken and Berenschot, 2016; Berenschot, 2018) are less discussed in the debate. Thus, this study elaborates on clientelism politics practice in the transition society bypassing the dichotomy perspective.

Drawing on the case of candidacy and coalition processes in the local election for Governor and Deputy Governor of NTT period 2018-2023, this study describes cleavage clientelism politics and its variant through understanding the work of clientelistic relation between the political party, social identity actor, and political class. Data collection entails observations, depth interviews, and desk review which then analyzed using explanation technique by combining clientelism theory - relation of exchange (Hopkin, 2006; Aspinall and Sukmajati, 2016), with some theories including primordialism - relation based on social identification, and instrumentalism - relation established on rational choice (Hutchinson and Smith, 1996), identity politics - politics built on ethnicity, religion, race, biopolitics, body, and gender (Heller and Riekmann, 1996), and materialist or money politics - politics manifested in forming of exchange money, goods, service, programs, and government's support with votes (Aspinall, 2010).

I argue that clientelism practice in local democracy delivers several authentic variants where identity politics and materialist or money politics are only the two among others. It presents in the local democracy of NTT where the variant surpasses all the existing categorical descriptions. The clientelism practice shows other variants that can only be understood by combining the ideas of primordialist and instrumentalist with identity and materialist or money politics. It addresses the missing relational explanation between patronage and clientelism politics with social identity and materialistic which clientelism politics is limitless to both identity and money politics. This paper is outlined into three sections. The first section elaborates the texture of local politics where democracy and clientelism are integrated, and social identity actors, political parties, and the political class as an intermediary. The second section discusses the cleavage of clientelism politics in some authentic variants exceeding identity and money politics. The third section is the conclusion.

\section{Results and Discussion}

\subsection{Local Democracy and Clientelism: Political Texture and The Dimension of Relation}

NTT local democracy is undeniably bound to the structure of political power that once dominated Indonesia during the New Order where the existence of local democracy was controlled through the system of autocratic clientelism and patrimonialism (Jackson, 1978; Crouch, 1979). The sultanic oligarchy system allowed Soeharto to monopolize authority and violence like a godfather and at the same time controlled economy, bureaucracy, military, and political parties (Winters, 2014). The oligarchy power succeeded in adapting to democracy till the local level. The established democratic political power in turn is the hybridization of democracy and oligarchy with strong clientelism (Hadiz and Robison, 2004). Afterward, the ongoing change of the political system is inadequate to optimally stimulate the establishment and the consolidation of democratic power but sustaining clientelism practice. This power is 
then absorbed by the local level establishing democratic political power in the form of democracy and oligarchy with strong clientelism (Hadiz and Robinson, 2004).

The adaptation is strengthened by the existing crisis at political parties. The state subsidy declined (Mietzner, 2007) and at the same time, the political parties at the local level experienced a political trust crisis with voters as the consequence of poor performance. The political parties in NTT tried to cope with the crisis by hijacking social trust and utilizing the existing clientelistic relations among the social identity actors (Rohi, 2016). This is the most effective and fastest method because it can provide predictions, indicators of effectivity, and reciprocal assurance in return (Bjarnegård, 2012). Nevertheless, it comes with the consequence of expensive political costs. The shifting of the electoral system from closed proportional to open proportional, many new changes within the stages of elections, the increase in parliamentary and candidacy threshold are also some of the factors that escalate the political costs. Whilst the local topography condition in NTT which consists of islands with minimum and limited infrastructures made the various electoral activities more costly.

Furthermore, democracy provides a wide space of political activity for the locality. The national electoral events consist of presidential and legislative elections, however, at the local level besides these two elections, there are governor, mayor, and regent elections. In that context, the political parties change their financial strategy. One of the essential changes is to hand over the political cost responsibilities to candidates or those who use the political party as "vehicles" (Mellas, 2018; Haryanto et. al, 2018; Hendrawan et. al, 2021). Hence, when political cost increased and demands to be self-managed, clientelism by political parties is inevitable for their financial sustainability. The empirical condition eventually allows a political party to expand consolidation of its clientelism network to various relations with similar characters particularly establishes its relations with the power of social identity and political class. By having a clientelistic relation with social identity actors, consolidations and gaining support from society, and buying votes can be achieved. Moreover, a partnership with the political class can be capitalized on the financial needs of a political party.

Concurrently, the social identity actors and the political class have interests to access the resources and secure their position in the state. Therefore, a patron-client relation is the most guaranteed option. The patron-client relations are settled through the identification of social identities then followed by materialistic support as its warranty or vice versa. At this point, the local political dimension with its democracy events is congested with clientelism practice. Clientelism is the spirit of the local politics and its compass directing to the state. The political system and party can be substituted, but the clientelism practice in the dimension of local politics is irreplaceable. Clientelism thrives in politics as in social and state - government and bureaucracy - dimension. Clientelism and democracy, therefore, become one in the NTT local politics. The two become one is bridged by the political class, social identity actor and political party through creating the clientelism dimensions of relation as mentioned above.

\subsection{Cleavage Clientelism: Beyond Identity and Money Politics}

Both democracy and clientelism are constitutes of the established relations between political parties, identity actors, and political class taking place in the form of primordial and instrumental clientelism. Both forms are manifested through identity and money politics where the linkage between the two forms clientelism variants surpassing the organic pattern of identity and money politics. On one hand, the dimension of clientelistic relations between political party and social identity actors - ethnic groups, religious, and geospatial - can operate by itself as the identity primordialism, or together with money politics producing 
another authentic variant of political clientelism - materialist primordialism. On the other hand, another dimension of clientelistic relations between political parties and political classes is evident. In the context of NTT, the political class is produced by state actors and political elites and their families as well as non-state actors with access to the state such as retired top officers and entrepreneurs deriving revenue from the state (Vel, 2008). These actors manifest the relation in instrumentalist clientelism in two ways, identity and materialist instrumentalism.

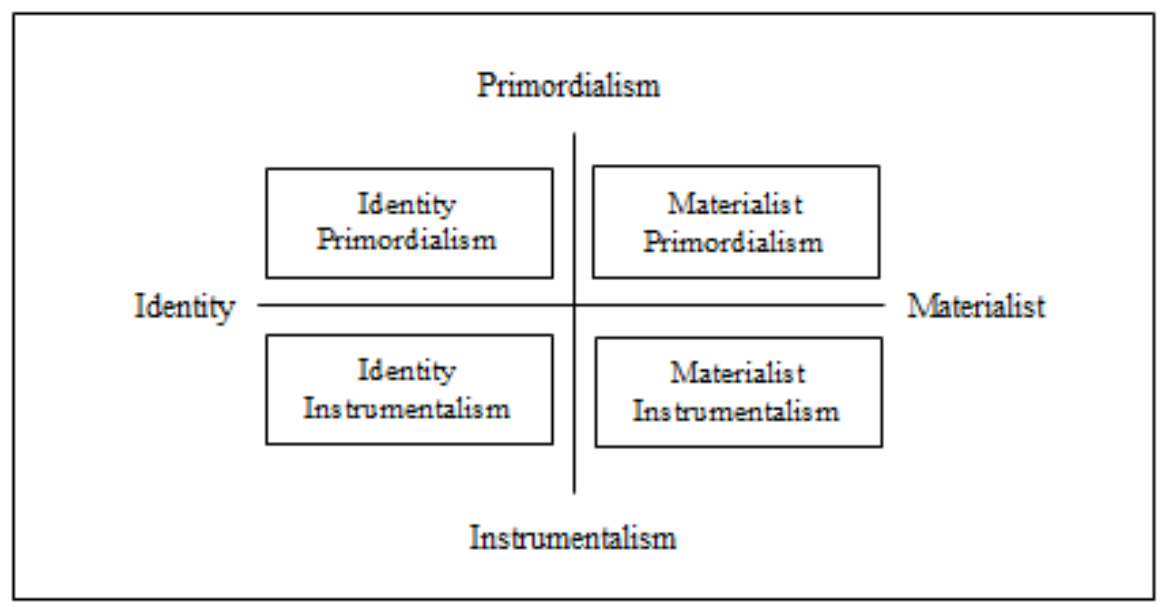

Fig. 1. The Cleavage of Clientelism

First, identity primordialism. The clientelistic relation is consolidated by establishing social identity actors as members, managers of a political party, and candidacy processes of the governor and deputy governor, mayor and deputy mayor, and regent and deputy regent. It can be found in the political praxis of parties in NTT, even superior parties like Golkar and PDIP. The parties established a religious, ethnic, and geospatial relation of primordial identity. These parties later consolidate relations of identity with the characteristics of ethnicity and geospatial in Flores, Timor, and Sumba as their basis areas. The consolidation forms identity politics within the parties in the shape of groups of Catholics-Flores, Catholics-Timor, Protestants-Timor, Protestants- Sumba, Catholics-Protestants-Flores, and ProtestantsCatholics-Timor.

Second, materialist primordialism. The relation of social identity consolidation is followed by money politics. Social identity actors receive donations from a political party and they reciprocate by ensuring members of ethnic groups, religious followers, and geospatial return the favors to the patron. Rather, the mediators will distribute donations to the members and followers. The local election in Timor and Sumba, for instance, the practice of clientelism are in the form of gratifications such as building constructions donations such as service of construction permit and land certificates, materials for constructions, hand tractor until free electricity installation for members of the church. In other places, the manifestation comes in the form of donations of money and program charity such as bridges, roads, and irrigation infrastructures. The donation will be distributed to members of the church by the patron and in return, they will give their vote during the election. The relation and distribution of donation are established on the basis of similarity and packaged in materials and goods. 
Third, identity instrumentalism. It operates material exchange followed by identifications of social identity as instruments to accomplish political purposes and interests. Hence, the character is also primordial but different from identity and materialist primordialism. It existed in relations between political party and political class with a bureaucracy background. The practice appears in the bureaucracy mutation as part of the agreements and sharing power between the winning coalition parties. It is inseparable from the strategy of political parties to create a new source of funding from the state outside the subsidy.

Evidently, several offices are traceable sources of political finance. The offices and agencies are included Procurement of Goods and Services of Regional Government, Health Office, Regional Public Hospital and Bank, Public Works and Housing Office, Education and Culture Office, Regional Personnel Agency, Regional Finance Agency, and Inspectorates. The informants link the mutation of bureaucracy officers with the close people of the governor and the winning coalition parties. The trusted and chosen people will be appointed as the head of offices and other important positions within the offices and agencies.

It is no surprise that corruption with a fantastic number of cases arises in these agencies and offices such as Medical Devices Funding (49,4 Billion), Pancasila Monument (28 Billion), NTT Fair (29,9 Billion), Non-Formal Education (77 Billion), Funding of Business Credit Facility of Bank of NTT (127 Billion), and many more. Most of the cases that emerge, or are reported are not investigated nor revealed due to the practice of identity instrumentalist clientelism. Fourth, materialist instrumentalism operates on the basis of exchanging interests based on a political and economic rational choice between patron and client. This clientelistic manifestation is implemented on the basis of materialistic exchange (i.e, money, goods, or services) and the relations will be maintained as long as the needs of the actors are met. This kind of clientelism form is aligned with money politics.

Actors who associate with political parties in the exchange are mainly entrepreneurs business actors financially nurtured by the state funding. The empirical phenomenon shows that these actors are local and national entrepreneurs with strong associations and control development projects in several government institutions. To protect access to these projects, the entrepreneurs establish solid instrumentalist and materialistic clientelism relations with political parties. Entrepreneurs become the clients of political parties through a clientelistic relation. They support the parties financially for several political events and at times fund the activities directly. The events are included presidential-legislative-regional elections, party congress, and party national and local meetings and conferences. Some findings suggested that they also financially support the personal needs of the elites in the parties. This support is a reward for the distribution of the state's profits by the political parties.

Parties distribute profit by influencing and controlling the process of decision-making in the parliament, bureaucracy, and local government. The influence and the control are accomplished through local and national fractions in the parliament or directly by bureaucrats in the clientelism network of political parties. For instance initiating local policy or changes that are profitable for parties and their clients, and to make sure entrepreneurs won government projects tender for they are the clients of political parties.

The relation is a purely materialistic exchange of interest within the complex, quiet and clandestine characters. Each actor economically and politically consolidates and arranges an exchange to avoid contra-productive materialistic exchange. There is not one single political party that establishes connections with only one entrepreneur. One political party has clientelistic relations with several entrepreneurs. Conversely, there is not one single entrepreneur that develops clientelistic relations with one political party. Every entrepreneur has clientelistic relations with several political parties particularly the winning coalition. 


\section{Conclusion}

The practice of clientelism politics in local democracy depends on the dimension of relation. The dimensions refer to the social, economic, and political interests to state resources as a target of exchange relation reciprocally between social identity actor, political class, and party. Clientelism politics become a strategy of the actors to access state resources.

Accordingly, the cleavage of clientelism is undeniable. Its cleavage follows the dimension of the relationship among local democracy actors which consists of the political class, social identity, and political party. The first dimension operates through clientelist relations between social identity actors and political parties. The dimension produces two variants of clientelism politics that are identity primordialism and materialist primordialism. The second dimension worked by way of clientelist relation between political party and political class with mostly profiled as a bureaucrat or formal state actor. It delivers a variant of clientelism as identity instrumentalism. The last dimension runs thru the clientelist relation between political party and political class with an entrepreneur or informal state actor. Its dimension generates a materialist instrumentalism variant of clientelism.

The practice of clientelism politics in local democracy in the context of transition society was strongly dominated by the political class is not limited to identity and money politics. The cleavage of clientelism is dividing into a number of authentic variants. The variants are shaped by identity politics, money politics, and the linkages between both identity and materialist. Eventually, this study provides an answer to the missing explanation from neither feudalmodern nor old-new clientelism dichotomous point of view.

\section{References}

[1] Allum, F., \& P. Allum. 2008. Revisiting Naples: Clientelism and Organized Crime. Journal of Modern Italian Studies 13(3), 340-365.

[2] Aspinall, E. 2010. Indonesia: The Irony of Success. Journal of Democracy 21(2), 2034.

[3] Aspinall, Edward, \& Mada Sukmajati. ed. 2016. Electoral Dynamics in Indonesia: Money Politics, Patronage and Clientelism at the Grassroots. Singapore: NUS Press.

[4] Berenschot, W. 2018. The Political Economy of Clientelism: A Comparative Study of Indonesia's Patronage Democracy. Comparative Political Studies 51(12), 1563- 1593.

[5] Bjarnegård, E. 2012. Who's the perfect politician? Clientelism as a determining feature of Thai Politics. Party Politics in Southeast Asia 160-180. Routledge.

[6] Crouch, H. 1979. Patrimonialism and military rule in Indonesia. World Politics 31(4), 571-587.

[7] Fossati, D., E. Aspinall, B. Muhtadi, \& E. Warburton. 2020. Ideological Representation in Clientelistic Democracies: The Indonesian Case. Electoral Studies 63, 102111.

[8] Hadiz, Vedi, and Richard Robison. 2004. Reorganising power in Indonesia: The politics of oligarchy in an age of markets. Routledge.

[9] Haryanto, D. D. Cahyati, \& Y. H. L. Lopo. 2018. Pembiayaan Kampanye Calon Usungan Partai Politik di Pilkada: Kasus Pilkada Kota dan Kabupaten Madiun 2018 in Pembiayaan Pemilu di Indonesia, ed. M. Sukmajaati and A. Perdana. Jakarta: Bawaslu RI.

[10] Heller, Agnes, and Sonja Puntscher Riekmann. 1996. Biopolitics: the politics of the body, race and nature. Ashgate Publishing. 
[11] Hendrawan, A., W. Berenschot, \& E. Aspinall. 2021. Parties as Pay-Off Seekers: Preelectoral Coalitions in a Patronage Democracy. Electoral Studies 69, 102238.

[12] Hopkin, J. 2006. Clientelism and Party Politics. London School of Economics and Political Science. Philadelphia: APSA Annual Meeting, 31 August - 3 September. Panel 46-18, Concept Analysis: Unpacking Clientelism, Governance and Neoliberalism.

[13] Hutchinson, John, \& Anthony D. Smith. 1996. Ethnicity. New York: Oxford University Press.

[14] Jackson, Karl D. 1978. "Bureaucratic Polity." in Political Power and Communications in Indonesia, ed. Karl D. Jackson and Lucien W. Pey. Berkeley: California Univ. Press.

[15] Kitschelt, Herbert, and Steven I. Wilkinson, ed. 2007. Patrons, clients and policies: Patterns of democratic accountability and political competition. Cambridge University Press.

[16] Klinken, Gerry van. 2007. Perang Kota Kecil: Kekerasan Komunal dan Demokratisasi di Indonesia. Jalarta: KITLV \& Yayasan Obor.

[17] \& Ward Berenschot. ed. 2016. In Search of Middle Indonesia: Kelas Menengah di Kota-Kota Menengah. Yayasan Pustaka Obor Indonesia.

[18] Mason, T. D. 1986. Land Reform and the Breakdown of Clientelist Politics in El Salvador. Comparative Political Studies 18(4), 487-516.

[19] Mellaz, August. 2018. Personal Vote, Candidate-Centered Politics, dan Pembiayaan Pileg 2014 in Pembiayaan Pemilu di Indonesia, ed. M. Sukmajati and A. Perdana. Jakarta: Bawaslu RI.

[20] Mietzner, M. 2007. Party Financing in Post-Soeharto Indonesia: Between State Subsidies and Political Corruption. Contemporary Southeast Asia 238-263.

[21] Piattoni, Simona, ed. 2001. Clientelism, Interests, and Democratic Representation. Cambridge: Cambridge University Press.

[22] Rohi, Rudi. 2016. East Nusa Tenggara: Patronage Politics, Clientelism and The Hijacking of Social Trust in Electoral dynamics in Indonesia: Money politics, patronage and clientelism at the grassroots, ed. E. Aspinall \& M. Sukmajati. NUS Press.

[23] Tidey, S. 2012. A Devided Provincial Town: The Development from Ethnic to Calss Segmentation in Kupang, West Timor. City \& Society 24-3. pp. 302-320.

[24] Vel, Jacqueline. 2008. Uma Politics: An Ethnography of Democratization in West Sumba, Indonesia 1986-2006. Leiden: KITLV.

[25] Winters, J. A. 2014. Oligarchy and democracy in Indonesia.Beyond Oligarchy. Cornell University Press. 11-34. 